\title{
ЮРИДИЧНІ НАУКИ
}

УДК: 347.97 (477)

\section{ПРИМУСОВЕ СКАСУВАННЯ ДЕРЖАВНОЇ РЕЕСТРАЦЇ̈ ЮРИДИЧНОЇ ОСОБИ ЗА ПОДАННЯМ ОРГАНУ ВИКОНАВЧОЇ ВЛАДИ ЯК ЗАСІБ АДМІНІСТРАТИВНОЇ ВІДПОВІДАЛЬНОСТІ}

\author{
(C) А. П. Нікітіна \\ Розглядається сфера владних повноважень державних органів виконавчої влади щзодо ініціювання \\ припинення юридичної особи. Характеризуються адміністративно -правові відносини між державними \\ органами влади і юридичною особою , щодо якої прийнято рішення про примусову ліквідацію. \\ Ключові слова: виконавча влада, примусове скасування, адміністративна відповідальність, подання \\ органу виконавчої влади
}

The area of imperious credentials of executive authorities is examined in relation to initiator of stopping of legal entity. Administrative-legal relations between the public authority and legal entity in relation to which a decision is accepted about the forced liquidation are characterized.

Keywords: executive power, forced abolition, administrative responsibility, executive power organ presentation

\section{1. Вступ}

Удосконалення законодавства, яке регламентує підстави та порядок примусового скасування державної реєстрації юридичних осіб, у контексті реформування та кодифікації адміністративного законодавства України $є$ нагальною потребою сьогодення. Дослідження проблеми скасування державної реєстрації діяльності юридичних осіб у примусовий спосіб за ініціативою органів виконавчої влади $€$ досить актуальним. Чинним адміністративним, господарським та цивільним законодавством сформульовано підстави, за якими державні органи виконавчої влади мають право ініціювати шляхом подання до суду відповідної позовної заяви скасування державної реєстрації юридичної особи.

\section{2. Постановка проблеми}

Питання примусового скасування державної реєстрації юридичної особи за поданням органів виконавчої влади, які $є$ суб'єктами публічноправових відносин в їхніх працях не отримали детального аналізу, оскільки останні були спрямовані на дослідження відповідальності юридичних осіб. Мета та завдання дослідження полягає у встановленні сутності правових відносин, які складаються при поданні органами виконавчої влади адміністративних позовів до адміністративного суду про примусове скасування державної реєстрації юридичної особи.

\section{3. Літературний огляд}

Питанню щодо визначення змісту поняття державного примусу присвячено ряд наукових праць як радянських, так і вітчизняних учених-правників, серед яких М. Н. Марченко, Б. Т. Базилєв, В. М. Корельський, М. Д. Шаргородський,
О. Е. Лейст, Н. С. Малеін [1]. Узагальнене визначення запропонував С.М. Алфьоров: державний примус - психологічний або фізичний вплив державних органів (посадових осіб) на певних осіб 3 метою спонукати, примусити їх виконувати правові норми. Він, як правило, виступає у двох формах: судовій та адміністративній.

А. М. Подоляка зазначає, що державний примус, з одного боку, розглядається як невід'ємна складова здійснення державної влади, як іiі визначальний засіб (метод), як головна ознака держави загалом, а з іншого - державний примус - не самоціль, а наслідок певної поведінки різних соціальних суб'єктів, зокрема, такої поведінки, яка відхиляється від вимог правових норм, становить загрозу відносинам, що цими нормами регулюються та охороняються, і застосовується з метою усунення такої поведінки.

\section{4. Викладення основного матеріалу}

Можна стверджувати, що державний примус $\epsilon$ одним із засобів державного регулювання. Як слушно зазначав Г. М. Калетнік, “адміністративні (організаційно-розпорядчі) методи полягають у впливі суб'єкта управління на керований об'єкт за посередництвом владно-розпорядчих вказівок i організаційно-структурних упорядкувань. Як уже зазначалося, організаційні i розпорядчі методи управління є методами прямої дії, оскільки мають директивний, обов'язковий характер. Вони грунтуються на таких управлінських відносинах, як дисципліна, відповідальність, влада, примус " [2]. Ліквідація - це такий спосіб припинення юридичної особи, при якому на майбутнє неможливі будь-яка іiі діяльність та існування i який пов'язаний 3 ліквідацією ऑii справ та майна й відсутністю правонаступника (тобто припинення юридичної 
особи здійснюється без переходу їі прав та обов'язків до інших осіб). Ліквідацію може бути здійснено як на добровільній основі, так і в примусовому порядку. Звісно, найчастіше ліквідація є добровільною (такою, що здійснюється позасудовими органами, зазвичай на підставі рішення власників). Але останнім часом усе більшого застосування на практиці набуває примусова ліквідація юридичної особи за рішенням суду. Такий спосіб $є$ проявом компетенції відповідного адміністративного суду застосувати до порушника адміністративну відповідальність у вигляді санкції, яка спричиняє скасування державної реєстрації й повну ліквідацію правопорушника. Перелік підстав для постановлення судового рішення про скасування державної реєстрації юридичної особи міститься в Законі України "Про державну реєстрацію юридичних осіб та фізичних осіб підприємців " [4], Цивільному та Господарському кодексах України [5; 6], Законі України "Про господарські товариства " та в деяких інших нормативних актах. Найбільш вживаною 3 усіх підстав примусової ліквідації підприємств на практиці $\epsilon$, звісно, визнання юридичної особи банкрутом. Усі ж інші підстави примусового припинення юридичних осіб у згаданому Законі називаються такими, що не пов'язані з банкрутством юридичної особи, - саме вони й будуть розглянуті в цій роботі. Примусове скасування державної реєстрації та подальша ліквідація юридичної особи є найважчою за наслідками санкцією.

Рішення органу виконавчої влади про подання позову до адміністративного суду щодо скасування державної реєстрації юридичної особи $\epsilon$ управлінським рішенням, оскільки реалізує його владну компетенцію. Основою для цього є відповідна нормативна база, яка визначає підстави для прийняття відповідного рішення й межі повноважень, які надають органу виконавчої влади право приймати рішення про подання позову про скасування державної реєстрації юридичної особи.

Будь-яке управлінське рішення державного органу виконавчої влади спрямоване на реалізацію завдань i мети цього органу. Тобто прийняття державним органом виконавчої влади рішення припинити юридичну особу є насамперед способом реалізації державним органом відповідних завдань, покладених на нього галузевим законодавством. Таким чином, наприклад, якщо територіальний орган державної податкової служби приймає рішення подати позов про скасування державної реєстрації підприємства, це рішення повинно бути інструментом реалізації завдання державної податкової служби. Отже, одним із завдань державної податкової служби (або іншого органу виконавчої влади) $є$ діяльність, спрямована на примусове припинення юридичних осіб (скасування державної реєстрації) у разі порушення цими особами законодавства України, яке тягне за собою застосування адміністративно-правової санкції у вигляді скасування державної реєстрації юридичної особи та іiі ліквідації. Примусове скасування державної реєстрації юридичних осіб за ініціативою державних органів виконавчої влади $є$ складовою адміністративно-правових відносин, які встановлюються між суб' єктом владних повноважень та відповідною юридичною особою 3 приводу іï примусового припинення.

Ю. П. Битяк дав дефініцію адміністративноправових відносин: це суспільні відносини у сфері державного управління, учасники яких виступають носіями прав і обов'язків, урегульованих адміністративним правом [2].

Таким чином, адміністративно-правові відносини складаються 3 певних відносин між компетентним органом виконавчої влади та іншими учасниками, в яких орган виконавчої влади має право застосувати організаційно-правові засоби впливу на відповідні суспільні відносини, у тому числі у зв'язку 3 примусовим скасуванням державної реєстрації юридичних осіб, які за своїм характером можуть бути як адміністративно-правовими, так і цивільно та кримінально-правовими, зокрема, шляхом встановлення відповідних заходів юридичної відповідальності.

У працях В. Б. Авер'янова, Л. Л. Попова, Є. В. Додіна, Д. М. Бахраха та інших учених показано самостійне значення адміністративних правопорушень як соціально негативних явищ, обгрунтовано необхідність їх цілеспрямованого дослідження як основного, а не побічного об’єкта деліктологічних досліджень.

У науковій теорії сформувались такі основні напрями досліджень: перший - вивчення стану адміністративної деліктності, другий - вивчення основних факторів, що впливають на стан адміністративних правопорушень.

В нормах Цивільного та Господарського кодексів України вживається термін “скасування державної реєстрації суб'єкта господарювання ”, хоча Закон України "Про державну реєстрацію юридичних осіб та фізичних осіб - підприємців ”, яким встановлено порядок державної реєстрації суб'єктів господарювання та, відповідно, іiі скасування, містить такі поняття, як “державна реєстрація припинення юридичної особи” та “державна реєстрація припинення підприємницької діяльності фізичної особи".

Примусове скасування державної реєстрації юридичної особи є наслідком застосування засобів правової охорони відповідних адміністративноправових відносин. Одним із заходів правової охорони є застосування юридичної відповідальності. Характерною ознакою елемента юридичної відповідальності є їі примусовий характер. За своїм характером юридична відповідальність являє собою державний примус у виконанні вимог права.

Набуваючи правових форм, державний примус стає юридичною відповідальністю, що передбачає виконання правового обов'язку за порушення норм законодавства, яке регламентує діяльність юридичних осіб. Юридична відповідальність являє собою один 3 видів ретроспективної соціальної відповідальності перед суспільством за вчинене правопорушення в особі держави [9]. Разом 3 
ретроспективною соціальною відповідальністю, відповідальність завжди спрямована в бік минулої поведінки особи. Із цього приводу в науковій літературі розроблено положення про позитивну та активну відповідальність. Така відповідальність спрямована на майбутню поведінку суб'єкта, на запобігання в майбутньому неправомірним діям 3 його боку. Зазначимо, що поняття "позитивна соціальна відповідальність" і “юридична відповідальність" збігаються як родове та видове поняття. При цьому здійснення позитивної відповідальності пов'язане із застосуванням засобу переконання, оскільки метод примусу в цьому випадку застосовувати неприпустимо.

Таким чином, термін “відповідальність” вживається як синонім до слів “зобов'язання”, “обов'язок”. Це означає, що в разі невиконання встановлених законодавством правил і норм щодо порядку здійснення діяльності юридичною особою, наприклад, підприємницької, юридична особа або іiі посадові особи в примусовому порядку зобов'язані виконати вимоги законодавства, які були порушені. Цей примус здійснюється відповідними державними органами.

Питання визначення підстав примусового скасування державної реєстрації юридичних осіб та порядку реалізації державним органом компетенції щодо примусового скасування державної реєстрації юридичної особи потребує подальшого вдосконалення шляхом внесення відповідних змін до адміністративного законодавства.

За змістом положень Кодексу України про адміністративні правопорушення (ст. 9-16) [9] адміністративна відповідальність - це вид юридичної відповідальності громадян і службових осіб за вчинення ними адміністративних правопорушень. Таким чином, по-перше, Кодекс України про адміністративні правопорушення не розглядає юридичну особу як суб'єкта, який несе адміністративну відповідальність; по-друге, усі дефініції адміністративної відповідальності мають дослідний характер. Так, Ю. П. Битяк, Л.В. Коваль вважають, що адміністративна відповідальність - це застосування до правопорушників заходів примусу. €. В. Додін наголошує, що адміністративна відповідальність - це визначення обмежень майнових, а також особистих благ i інтересів за здійснення адміністративних правопорушень. На думку I. П. Голосніченко, адміністративна відповідальність - це сукупність адміністративних правовідносин, які виникають у зв'язку із застосуванням до суб'єкта проступку адміністративних стягнень. 3 огляду на це $\mathrm{B}$. К. Колпаков вважає, що наведеним дефініціям бракує вказівок про виконання суб'єктом протиправних дій, застосовуваних за їх вчинення заходів адміністративного примусу. Тому на підставі викладеного слід зазначити, що адміністративна відповідальність - це примусове, 3 додержанням встановленої процедури застосування правомочним суб'єктом передбачених законодавством за вчинення адміністративного проступку заходів впливу, які виконані правопорушником. Вважаємо за доцільне висловити власну думку 3 приводу визначення адміністративної відповідальності за правопорушення, які спричиняють примусове скасування державної реєстрації юридичних осіб.

По-перше, суб'єктом цих правопорушень разом $з$ керівним складом виступає безпосередньо “винна” юридична особа.

По-друге, правопорушення, вчинені юридичною особою, є дією або бездіяльністю щодо порушення приписів цивільного, господарського, податкового, фінансового законодавства.

По-третє, ці правопорушення посягають на суспільну безпеку, є порушеннями в публічноправової сфері, тому заходи впливу до юридичної особи застосовують саме державні органи.

Примусове скасування державної реєстрації юридичної особи є результатом реалізації державним органом своїх повноважень щодо припинення небезпечних наслідків від діяльності юридичної особи. Дискусія стосовно концептуальних підходів до визначення поняття “адміністративна відповідальність " досі не припиняється, що $є$ об'єктивним явищем, оскільки адміністративне право як галузь досі зазнає змін, реформується, крім того, з'явилося нове покоління вчених 3 іншими поглядами. Фактично на сьогодні немає єдиної точки зору щодо понять “юридична відповідальність" та “адміністративна відповідальність ". Як пише С. Потапова, певну негативну роль у цьому відіграє той факт, що до сьогодні в чинному законодавстві України не має законодавчого визначення того, що являє собою адміністративна відповідальність як інститут адміністративного права, як вид юридичної відповідальності та як засіб покарання правопорушників адміністративних норм [10].

Таким чином, питання визначення дефініції адміністративної відповідальності $є$ відкритим, а кожен автор пропонує своє, суб'єктивне його розуміння. Так, М. Студеникіна вважає, що під адміністративною відповідальністю найчастіше розуміють застосування частини заходів адміністративного примусу, а саме адміністративних стягнень.

На думку Г. П. Бондаренка, адміністративна відповідальність - це форма реагування держави на правопорушення, яке полягає в застосуванні повноважними державними органами, службовими особами, громадськістю до винної особи адміністративних санкцій у межах i порядку, встановлених законодавством, це обов'язок правопорушника відповідати за свою протиправну поведінку й зазнавати за неї несприятливих наслідків, передбачених санкцією правової норми. I. А. Галаган вважає, що під адміністративною відповідальністю слід розуміти застосування у встановленому порядку уповноваженими на це органами й службовими особами адміністративних стягнень (сформульованих у санкціях адміністративно-правових норм) до винних у вчиненні адміністративних проступків, які містять державний і громадський осуд, засудження їх особи 
та протиправного діяння, що виявляється в негативних для них наслідках, має на меті їх покарання, виправлення й перевиховання тощо.

С. Т. Гончарук зазначає, що адміністративна відповідальність як різновид правової відповідальності - це специфічна форма негативного реагування з боку держави в особі ії компетентних органів на відповідну категорію протиправних проявів, передусім адміністративних проступків, згідно з якою особи, які скоїли правопорушення, повинні відповідати перед повноважними державними органами за свої неправомірні дії та понести за це адміністративні стягнення у встановленому законом порядку [9].

Заслуговує на увагу точка зору В. А. Авер'янова, відповідно до якої, адміністративна відповідальність - це різновид юридичної відповідальності, що являє собою сукупність адміністративних правовідносин, що виникають у зв'язку із застосуванням уповноваженими органами (посадовими особами) до осіб, які вчинили адміністративний проступок, передбачених нормами адміністративного права особливих санкцій адміністративних стягнень.

Отже, більшість вчених-адміністративістів розглядають адміністративну відповідальність як негативну обставину, що неминуче має настати за вчинення протиправного, адміністративно караного вчинку. При цьому, якщо говорити про примусове скасування державної реєстрації юридичної особи, то “негативна обставина" не має виховного характеру, а $\epsilon$ лише засобом, який фактично припиняє суспільно небезпечну діяльність або бездіяльність.

Таким чином, можна констатувати, що адміністративну відповідальність юридичних осіб можна визначити як певну процедуру щодо застосування до правопорушників (юридичних осіб) загальнообов'язкових санкцій, здійснювати які $\epsilon$ компетенцією державних органів.

Виділимо основні проблемні питання, які викладені в науковій літературі щодо визначення адміністративної відповідальності юридичних осіб. КУпАП, прийнятий у 1984 р., передбачає адміністративну відповідальність лише фізичних осіб. При цьому не викликає жодних сумнівів, що відповідно до чинного законодавства юридичні особи є суб'єктами адміністративної відповідальності. Передумовою для цього став розвиток новітніх для України соціально-економічних процесів, перехід на нову економічну модель. У наш час юридичні особи відіграють важливу роль в економічних відносинах, а також інших суспільних відносинах (аж до релігійних або політичних). На сьогодні законодавством України не передбачено єдиного документа, який регулював би підстави щодо адміністративної відповідальності юридичних осіб, визначав перелік стягнень, види стягнень, ступінь суспільної небезпеки вчинених проступків, їх деліктну тривалість тощо.

“Як відомо, юридичних осіб визнають суб'єктами правових відносин майже в усіх галузях права, за винятком тих, де це неможливо, виходячи 3 природи самих відносин (наприклад, у сімейному, кримінальному праві та деяких інших)", Адміністративна відповідальність юридичних осіб здійснюється на загальних принципах адміністративної відповідальності, має ознаки, які притаманні адміністративній відповідальності фізичних осіб, тобто вона встановлюється законами та іншими нормативними актами, норми яких утворюють самостійний інститут адміністративного права. Відповідно, юридичні особи як безпосередні учасники господарських, або навіть суспільнополітичних відносин, здійснюючи діяльність, визначену їх статутними документами та законодавством України, виявилися, крім іншого, суб'єктами деліктних відносин. У свою чергу, це зумовило необхідність для держави розробити та застосовувати відповідні механізми адміністративного примусу до юридичних осіб, переважно щодо господарюючих суб’єктів.

Ю. П. Битяк пише: “Вступаючи у правові відносини, юридичні особи, як і фізичні, своїми діями можуть реалізовувати надані їм права та виконувати обов'язки, тобто здійснювати правомірну поведінку, але можуть i порушувати їх, тобто здійснювати неправомірну поведінку. За окремі вияви неправомірної поведінки законодавством передбачено притягнення порушника, в нашому випадку юридичної особи, до правової відповідальності ”. Як висловився В. К. Колпаков, “законодавець уникає застосування щодо юридичних осіб таких термінів, як: “адміністративне правопорушення ", “адміністративна відповідальність ”, “адміністративне стягнення ”.

Як зазначає К. С. Бєльський, наукові визначення відіграють важливу роль у правознавстві та практичному житті. Вони мають важливе теоретичне значення у процесі пізнання конкретної галузі права, створення постійного капіталу галузі законодавства. Водночас практика свідчить, що для того, щоб поняття використовувалось у суспільстві ефективно, запам'ятовувалося людьми, ставало частиною їх правосвідомості, йому потрібно дати визначення в законодавчому акті. Визначення розкриває поняття, розгортає його зміст, вводить у суть. Це коротке пояснення, що має найвищу якісну цінність. Коротке пояснення суті правового явища у вступній частині нормативного акта дає змогу законодавцю більш точно і вільно формулювати правові норми.

\section{5. Висновки та перспективи подальшого дослідження \\ Підбиваючи підсумки вищесказаного, слід} зауважити, що досліджувати концептуальні підходи до відповідальності за правопорушення, які спричиняють примусове скасування державної реєстрації юридичних осіб, не пов'язане 3 їх неплатоспроможністю, необхідно для реального втілення в життя таких принципів адміністративної відповідальності, як невідворотність, справедливість покарання, законність тощо. 
Таким чином, примусове скасування державної реєстрації $є$ наслідком застосування до юридичної особи адміністративної відповідальності. При цьому адміністративна відповідальність юридичної особи визначається як комплекс певних заходів, які реалізуються повноважним органом влади i спрямовані на покарання юридичної особи, що тягне за собою для порушників обтяжливі несприятливі наслідки матеріального характеру, обмежувального характеру (призупинення дії ліцензій або дозволів) та/або спричиняють ї повне припинення (ліквідацію).

\section{Література}

1.Алфьоров, С. М. Адміністративне право України. Загальна частина [Текст] / С. М. Алфьоров. - К. : Центр учбової літератури, 2011. - 216 с.

2. Подоляка, А. М. Державний примус як метод впливу на учасників публічно-правових відносин (теоретичний аспект) [Текст] / А. М. Подоляка // Науковий вісник ЛДУ ВС. - 2009. - № 3. - С. 174182.

3.Державне регулювання економіки [Текст] : навч. посіб. / Г. М. Калетнік, А. Г. Мазур, О. Г. Кубай ; МОН України, ВНАУ. - К. : Хай-Тек Прес, 2011. - 427 c.

4.Закон України «Про державну реєстрацію юридичних осіб і фізичних осіб-підприємців» [Текст] / від 15.05.2003 p. (з наступними змінами i доповненнями)

5.Цивільний кодекс України: чинне законодавство із змінами та допов. на 01 листопада 2011 року [Текст] / Відповідає офіц. текстові. К.: Алерта:ЦУЛ, 2011. - 312 с.

6.Господарський кодекс України від 16 січня 2003 р. [Текст] / Відомості Верховної Ради України. 2003. - № 18, 19-20, 21-22. - Ст. 144.

7.Битяк, Ю. П. Адміністративне право України [Текст] : навч. посіб.; підр. / Ю. П. Битяк, В. М. Гаращук, О. В. Дьяченко та ін. - К. : Юрінком Iнтер, 2006. - $544 \mathrm{c}$.
8. Алёхин, А. П. Административное право Российской Федерации. Ч. 1.[Текст] / А. П. Алехин, Ю. М. Козлов; под ред. А. П. Алёхин. - М. : Теис, 1995. -528 с.

9. Кодекс України про адміністративні правопорушення [Текст] / Х. : Одіссей, 2011. - 256 с.

10. Колпаков, В. К. Адміністративна відповідальність (адміністративно-деліктне право) [Текст] : навч. посіб. / В. К. Колпаков. - К. : Юрінком Інтер, 2008. - 256 c.

\section{References}

1. Alferov, S. M. (2011). Administrativne right for Ukraine. General part. Kiev: Center of educational literature, 216.

2. Podolyaka, A. M. (2009). The State compulsion as method of influence on participants in public legal relations (theoretical aspect). Scientific announcer LDU VS, 3, 174-182.

3. Kaletnik, G. M., Mazur, A. G., Kubay, O. G. (2011). Government control of economy. Metaloxide-semiconductor Ukraine, VNAU. Kiev: Khay-tek Press, 427.

4. Law of Ukraine «On state registration of legal entities and physical persons-businessmen» (15.05.2003). With next changes and additions.

5. Civil code of Ukraine: current legislation with changes and dopov (2011). (Ofic answers. text). Ê.: Alerta:CUL, 312.

6. Economic code of Ukraine (2003). Information of Verkhovna Rada of Ukraine, 18, 19-20, 21-22, Item 144.

7. Bityak, V. M., Garaschuk, O. V. (2006). Administrative law of Ukraine. D'yachenko but other is K.: Yurinkom Inter, 544.

8. Alekhin, A. P., Trestlesthe, Yu. M. (1995). Administrative law of Russian Federation. Moscow: Teis, 1, 528.

9. A code of Ukraine is about administrative offences (2011). Odyssey, 256.

10. Kolpakov, V. K. (2008). Administrative responsibility (administratively deliktne right). KIEV: Yurinkom Inter, 256.

Нікітіна Аліна Петрівна, кандидат юридичних наук, доцент, кафедра «Правознавство», СЕГІ ТНУ імені В.І. Вернадського, вул. Лізи Чайкіної, 80, м. Севастополь, 299058

E-mail:nikitina7777@mail.ua 